\title{
Victimless Crime in Indonesia: Should We Punished Them?
}

\author{
Erika Magdalena Chandra* \\ DOI: https://doi.org/10.22304/pjih.v6n2.a1
}

Submitted: July 1, 2019 | Accepted: August 15, 2019

\begin{abstract}
Criminal act deserves punishment because it causes harmful to its victim. However, some criminal acts may be considered as victimless crime since the perpetrator is also the victim. They are, for example, drug abuse, gambling, and abortion. In many states, such as Netherlands, victimless crime like drug abuse are no longer considered to be punishable crime since they use harm reduction approach for drug abuse problem. Drug abuse is seen as a health issue, not a criminal law issue. On the contrary, Indonesia still considers victimless crime to be punishable. The Indonesian Penal Code and Narcotics Law, for example, regulate that drug abuse is punishable. Indonesian criminal policy uses zero tolerance approach. Hence, the criminal policy is to eradicate all narcotics offences, including drug abuse. Nevertheless, it is not a solution for the problem drug abuse. Furthermore, the number of Indonesian drug user is increased. The policy has also caused overcrowd in Indonesian correctional institutions. Considering its unique characteristic and contemplating the purpose of punishment itself, punishment for victimless crime should be reconsidered. This article aims to bring perspectives on this matter by using juridical normative method with regulation, comparative, and case study approaches.
\end{abstract}

Keywords: Indonesia, punishment, victimless crime.

\section{Kejahatan Tanpa Korban di Indonesia: Haruskah Kita Menghukumnya?}

\begin{abstract}
Abstrak
Salah satu penyebab mengapa suatu kejahatan dipidana adalah karena perbuatan tersebut menimbulkan kerugian yang diderita korban dari perbuatan tersebut. Namun ternyata terdapat suatu kejahatan dimana pelaku kejahatan sekaligus merupakan korban kejahatan tersebut. Kejahatan ini dinamakan kejahatan tanpa korban, contohnya penyalahgunaan narkotika dan obat-obatan terlarang lainnya, perjudian serta aborsi. Di negara lain, contohnya Belanda, kejahatan tanpa korban seperti misalnya penyalahgunaan narkotika dan obat-obatan terlarang lainnya tidak lagi merupakan perbuatan yang diancam pidana. Hal ini disebabkan untuk penyalahgunaan narkotika, Belanda menggunakan pendekatan harm
\end{abstract}

PADJADJARAN Journal of Law Volume 6 Number 2 Year 2019 [ISSN 2460-1543] [e-ISSN 2442-9325]

Lecturer of Criminal Law Department, Researcher of Criminal Policy Center Study, and Doctoral Candidate of the Faculty of Law, Universitas Padjadjaran, Jalan Dipati Ukur Nomor 35 Bandung, S.H., M.H. (Universitas Padjadjaran), erika.magdalena@unpad.ac.id 
reduction dimana pendekatan ini melihat penyalahgunaan narkotika sebagai permasalahan kesehatan bukanlah permasalahan hukum. Sebaliknya kejahatan tanpa korban di Indonesia, seperti penyalahgunaan narkotika dan obat-obatan terlarang lainnya, aborsi serta perjudian, masih dinyatakan sebagai perbuatan yang dilarang dan diancam pidana bagi yang melakukannya sebagaimana tercantum dalam KUHP dan Undang-Undang Narkotika. Seperti penyalahgunaan narkotika dan obat-obatan terlarang lainnya yang dikarenakan Indonesia menganut pendekatan zero tolerance, maka kebijakan kriminal Indonesia dalam penyalahgunaan narkotika dan obat-obatan terlarang lainnya adalah pemberantasan segala bentuk kejahatan narkotika termasuk penyalahgunaan narkotika dan obat-obatan terlarang lainnya. Namun hal ini tidak menyelesaikan permasalahan penyalahgunaan narkotika di Indonesia, bahkan jumlah pengguna narkotika makin tinggi yang selanjutnya berdampak pada kondisi overcrowding di beberapa lembaga pemasyarakatan di Indonesia. Mengingat karakteristik yang unik dari kejahatan tanpa korban ini serta tujuan dari dipidananya suatu perbuatan maka perlu dibahas lebih lanjut terkait pemidanaan terhadap kejahatan tanpa korban ini.

Kata kunci: Indonesia, kejahatan tanpa korban, penghukuman.

\section{A. Introduction}

According to Joseph F. Winterscheid in his article Victimless Crimes: The Threshold Question and Beyond, the debates on punishment for victimless crime is derived from the debates on mala in se and mala prohibita in anglo saxon system. ${ }^{1}$ They are known as recht delict and wet delict in the Indonesian Penal Code (KUHP), the chapters of "kejahatan" (crime) and "pelanggaran" (violation), according to Memorie van Toelichting ${ }^{2}$. The division of mala in se and mala prohibita lies on the attention of an act. In mallum in se or kejahatan, an act is already assumed as crime in nature; thus, it has to be punished. However, mallum in prohibitum or pelanggaran is not considered a crime act by nature. Somehow, it is considered as a crime just because it is regulated in law. Furthermore, Winterscheid says that, according to Smith and Pollack, victimless crime is considered malum prohibitum ${ }^{3}$. Nevertheless, it leads to never ending debates on punishment for victimless crime. There are always two contrary sides: the pros and the cons for punishment of victimless crime.

The definition of victimless crime can be found on Policy: Victimless Crime. The term is used to indicate an illegal or forbidden act that does not violate or threaten the right of other people. ${ }^{4}$ Based on the definition, it can be understood that the

1 Joseph F. Winterscheid, "Victimless Crimes : The Threshold Question and Beyond", Notre Dame Law Review, Vol. 52, Issue 5, p. 995.

2 E. Utrecht, Pengantar Dalam Hukum Indonesia, Cetakan Kesembilan, Jakarta : PT. Penerbitan Universitas, 1966, p. 82.

3 Joseph F. Winterscheid, loc.cit.

4 Liberal Democratic Party Austria, "Policy: Victimless Crime", https://ldp.org.au/wpcontent/uploads/policies/Policy-VictimlessCrimes.pdf, downloaded on 14 December 2016. 
debates on punishment for victimless crime is continuing up to now. Since it causes no harm effect characteristic that generally underlies a reason of punishment.

Indonesia regulates victimless crime such as drug abuse, abortion, and gambling as punishable crimes. Article 127 of the Law Number 35 of 2009 on Narcotics declares drug abuse as a crime act. In the article, a drug user can be punished for maximum four years in prison for Narcotics Class I, two years in prison for Narcotics Class II, and a year in prison for Narcotics Class I.

In addition, Indonesia also regulates that abortion, according to Article 346 of the Indonesian Penal Code, as a crime act. A woman who has an intention to abort pregnancy or order another party to do it can be punished for maximum four years in prison. Moreover, Article 303 of the Indonesian Penal Code stipulates that a perpetrator of gambling can be punished for maximum four years in prison or be fined.

Schur states, punishment for abortion, drug abuse, and gambling brings negative impact, such as appearance of secondary crime ${ }^{5}$. Because the acts are regulated as crime, perpetrators have to perform illegal activity to search commodities or services. ${ }^{6}$ Crime organizations may find perpetrators' needs as potential profit opportunity. The first level crime perpetrators will have willingness to pay large sum of money to get rare commodities or services.

Schur emphasizes that drug abuse punishment can trigger secondary crime rising since perpetrator demands rare commodity or service profitable for supplier. ${ }^{7}$ The high demand of rare commodity or service can create many secondary crime perpetrators who provide the demand. Drug producer, drug distributor, and drug dealer can appear to provide illegal drugs. Their acts are regulated as crime. Thus, there can be many criminals as the results. Such condition may be the reason of overcrowd in some Indonesian Correctional Institution (Lembaga Pemasyarakatan Indonesia).

With regard to the overcrowd, the following figure describes the amount of prisoners who committed special crime from December 2016 to May 2019. The types of special crime cover corruption, drug abuse, drug dealing, terrorism, illegal logging, human trafficking, money laundering, and genocide. Nevertheless, genocide will not appear in this figure because there is no genocide perpetrator in the period.

Figure 1. Occupants of Indonesian Special Crime Prisoner in December 2016 to May 2019

\footnotetext{
Edwin M. Schur, Crimes Without Victims-Deviant Behavior and Public Policy: Abortion, Homosexuality, Drug Addiction, New Jersey: Prentice-Hall, Englewood Cliff, 1965, p. 174.

6 Ibid., p. 174.

7 Ibid., p. 173.
} 

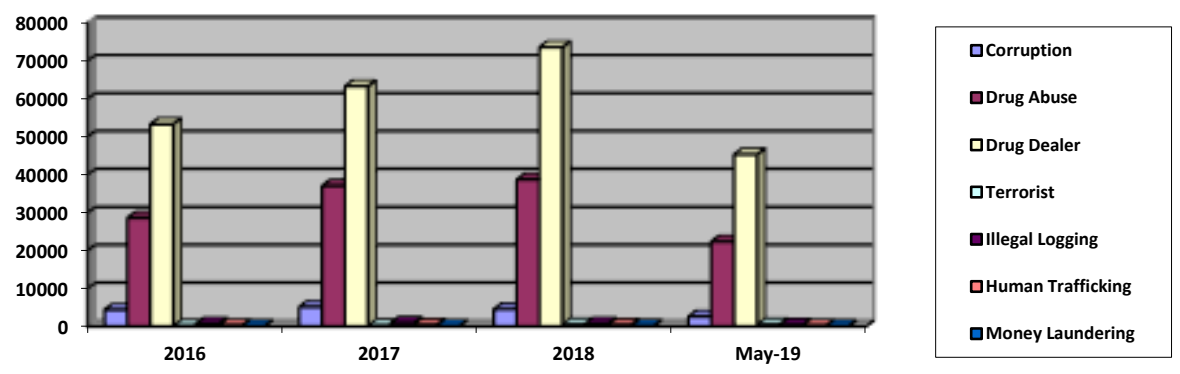

Source: Correctional Database System, May 2019

The figure above shows that from December 2016 to May 2019, drug dealing is the highest number of prisoners. The second largest group in the period is drug abuse. Thus, it can be concluded that drug dealer and drug abuser form the largest number of prisoners of special crime from December 2016 to May 2019. It is in line with Schur statement before that "It may also be useful to consider why the drug addict engages in much secondary crime while the deviants in the other two situations (abortion and gambling). Obviously, the immediate cause is the financial pressure the addict faces in attempting to support his habit ..."

This condition indicates that because secondary crime is profitable, more secondary crime perpetrator will arise to get the financial profit. This situation becomes one of the conditions that provoke overcrowd in correctional institutions.

The overcrowded correctional institution is the opposite of correctional institution in the Netherland. In the Netherland, drug abuse is not considered crime act but it is considered as health problem. The health problem needs physical and psychological treatments, not criminal law enforcement. The Netherland uses harm reduction approach to deal with drug abuse problem. ${ }^{8}$ Further, according to van Ooyen-Houben and Kleemans, after the revision of Opium Law in 1976, the Netherland tolerates drug abuse based on the principle that separation and punishment of drug abuser should be avoided because it gives nothing to meaningful benefit. $^{9}$

The World Health Organization (WHO, 2003) defines harm reduction as a concept that is intended to prevent or to reduce the negative consequences of

\footnotetext{
Peter Tak, The Dutch Criminal Justice System, CB Nijmegen: Wolf Legal Publishers, 2008, p. 21.

9 Marianne van Ooyen-Houben and Edward Kleemans, "Drug Policy: The "Dutch Model", Crime and Justice, July 2015, p. 166.
} 
health problems related to some behavior, ${ }^{10}$ such as illegal drugs, prison punishment, overcrowd, and mental health. ${ }^{11}$

The changing of law politics in Netherland on drugs, according to Waard, is a cause of the decrease of crime acts in the Netherland. ${ }^{12}$ Therefore, prison or correctional institution in the Netherland is relatively empty. This condition is the opposite of Indonesia, where the correctional institutions have high occupancy rate that leads to overcrowding problem.

As mention above, victimless crime has special characteristic that is different from other crimes. A unique characteristic of victimless crime is that the perpetrator is also the victim. There is no harm effect to another party than the perpetrators themselves. This makes the punishment for this crime has always become debatable for law experts and scholars.

It has been a common knowledge that the purpose of prohibition of an act is to prevent damage of society. ${ }^{13}$ In fact, the data from correctional database system show drug dealers and abusers as the largest group of prison occupants. A question that may arise is whether or not the victimless crime should be punished considering victim of this crime is the perpetrator her/himself? This article explores the issue by using juridical normative method with regulation approach and a comparison study to practices of other states.

\section{B. Punishment of Victimless Crime in Indonesian Criminal Law}

Since the beginning of the $20^{\text {th }}$ Century, victimless crime has become central of attention. There are debates on punishment of this crime. Some scholars disagree on the punishment of this crime, giving their argument, "how can one have a crime without a complaining victim?"14 Another argument states, it is impossible that there is no victim in a crime. According to this perspective, perpetrator of victimless crime should be punished like other crime perpetrators. ${ }^{15}$

10 Gerard Moore, et.al., "A Review of Harm Reduction Approaches in Ireland and Evidence from the International Literature", the Stationery Office, Dublin, May 2004, p. 12.

11 Status Paper on Prisons, "Drugs and Harm Reduction", WHO Regional Office, May 2005, http://www.euro.who.int/data/assets/pdf file/0006/78549/E85877.pdf, downloaded on May 28, 2018, pp. 56.

12 Jaap De Waard, "The Crime Drop in The Netherlands and other industrialized countries: Trends and possible explanations", Working Paper, May 2015, p. 15.

13 Mardjono Reksodiputro, "Perkembangan Hukum Pidana Materiil dan Formil Dalam Undang-Undang DI Luar KUHP (Catatan Sementara Tentang Pengaruhnya Terhadap Pembangunan Sistem Hukum Pidana Nasional)", this paper is presented at Lokakarya Perencanaan Pembangunan Hukum Nasional, Badan Pembinaan Hukum Nasional Kementrian Hukum dan Hak Asasi Manusia, Semarang, November 4, 2010, p. 3.

14 Edward Eldefonso, et.al., Principles of Law Enforcement, Second Edition, Canada: John Wiley \& Son, 1968, p. 310.

15 Ibid. 
Schur argues that victimless crime is a deviant behavior that is incorrect based on moral and regulation. ${ }^{16}$ According to Decker, as cited by Winterscheid, victimless crime is a non-forceful offense where the offence is done by consent adult that would not complain their offence and there is no harm or injury to other people who do not act similar offence. ${ }^{17}$ There are some victimless crimes as follows.

\section{Drug abuse}

Recently, drug is a center of attention in most states that criminalizes drug use. ${ }^{18}$ Many problems may be resulted from drug use. Beside the abuse of illegal drug, there are many crime issues, especially acquisitive crimes. There are also supply and possession problem in this issues. ${ }^{19}$

In addition to debates on the most effective way to deal with illegal drugs, there is a gap between law enforcement model that stresses on eradicate drug abuse problem and law enforcement; and medically-oriented model that emphasizes in treatment and harm reduction. ${ }^{20}$ The tension between the two models arises from different arguments on the objectives to be achieved to deal with drug abuse problem and the best way to solve the issue. There are two main categories in drugs as follows. ${ }^{21}$

\section{a. Pharmacological approach}

\section{i. Stimulants ('Uppers')}

This drug category stimulates nervous system. Crack, cocaine, and amphetamines are in this category.

\section{ii. Depressants ('Downers')}

Opposite to stimulants, depressants suppresses nervous system. Generally, it is used to reduce anxiety and causes sleepy. Drug in this category are barbiturates and benzodiazepines.

\section{iii. Analgesics}

Usually, this category is used as painkiller. Opium, morphine, heroin are included in this category.

\section{iv. Hallucinogens}

Hallucinogens tend to change perception and to alter emotion. This category covers LSD, magic mushrooms, and ecstasy. Cannabis is sometimes included as hallucinogen but, in fact, it is not absolutely suitable in pharmacological category.

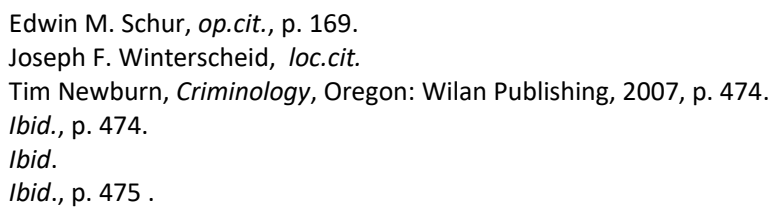




\section{b. A legal approach}

In England and Wales, the legal classification of drugs covers three categories or "classes" (A, B, and C) based on the harmful effects of each drug. Class A is considered the most dangerous, Class $B$ is averagely dangerous, and Class $C$ is less dangerous drugs. This classification is used to identify and to distinguish illegal drugs. There are some drugs that is illegal according to Misuse of Drugs Act 1971. The term "prohibited" includes production, supply, import, export, possession, and cultivation. Nevertheless, the use of drugs is not forbidden. Indonesia, different to England and Wales, prohibits to plant, to make, to distribute, to traffic, to possess, and to use drugs illegally. The violation is punishable according to the laws.

Indonesia regulates drugs by the Law Number 35 of 2009 on Narcotics and the Law Number 5 of 1997 on Psychotropic. Based on the Law Commentary, Article 2 (1), the Law Number $\mathbf{3 5}$ of 2009 on Narcotics, there are three classification of narcotics based on potential dependency. Class I and II are considered high potential dependency. Class I is limitedly permitted only for the purpose of research. Class II can be used for treatment and therapy. Class III can be used for treatment with less potential dependency.

Similar with the narcotics classification, psychotropic classification is divided also based on potential dependency. The Law Commentary, Article 2 (2), the Law Number 5 of 1997 on Psychotropic mentions that Class I and II as the most potential dependency effects. Class I is permitted only for research and prohibited for therapy. Class II can be used for therapy and medication. Class III have medical effect and medium potential dependency. Class IV have less potential dependency. Therefore, drugs, according to this classification, are used for therapy and or science purposes.

According to World Health Organization, drug addiction is a periodically condition or chronic toxicities that is caused by repeated illegal consumption of drugs, either synthetic or natural drugs. Moreover, there are some characteristics as follows. ${ }^{22}$

1. The eagerness to get or to consume the drugs in any ways.

2. Tendency to increase the dosage.

3. Generally, physically or psychologically dependence to drugs effect.

4. Negative effects that harms individual or society.

As mentioned previously, the punishment of drug abuse triggers secondary crime. It is because the demand of rare product may increase and there will be secondary crime perpetrator who fulfills the needs because the drug abuser (first crime perpetrator) would eager to consume it in any ways, including by paying a large amount of money. It is a profitable business for secondary crime perpetrators. They

22 Ibid., p. 122. 
will provide the needs of drug users by planting, making, distributing, and selling the drugs to profit in this business.

Since drug use is prohibited by law, a drug abuser is not welcomed in the society. They will gather to build a new sub-culture that is consists of fellow drug abusers and secondary crime perpetrators like drug dealer maintains the deviant behavior. ${ }^{23}$ This condition can be explained by sub-culture theory from Cohen. Based on the theory, lower-class youth struggle to reach the norms and values of society but they do not have means to reach it. Because they are desperate, they refuse to respect the norms and values, they create a new sub-culture as an alternative. ${ }^{24}$

\section{Gambling}

Gambling is one of business of organized crime. This business will die without gamblers, like a fish without water. ${ }^{25}$ This business emerges because gamblers always look for bookie and place to gamble. When gambling is considered as crime and punishable, there will be a lot of gamblers who seek for bookie and place to gamble in secret. This condition is in line with Schur statement that when drug abuse, abortion, and gambling are prohibited and punishable, they can caused secondary crime emerges due to financial profit from the situation. ${ }^{26}$ Albeit not only a person do gamble, the victims of gambling are the gamblers themselves.

There are always people who take advantage from gamblers through the lost gamble money. They also take profit from loan money for gambler to continue gambling. This business is very profitable. It usually develops into an organized crime that uses coercion to take profit. Ploscowe states, "The muscle and murder continue to be the ultimate weapons on which organized crime rest". ${ }^{27}$

In illegal gambling, in addition to lending money at high interest to gamblers, crime organization also involves in mass corruption. Usually they bribe and coerce government officer and law enforcement officer in order to protect their business. This condition makes many people want to legalize gambling. From their perspective, the legalization of gambling makes no more crime organization taking profit. ${ }^{28}$ In some states, gambling is legal but in Indonesia, gambling is illegal. Article 303 of the Indonesian Penal Code prohibits people who offer or provide opportunity to gamble without permission. The same article also prohibits people to gamble. The perpetrators face maximum four years or a fine.

Edwin M. Schur, op.cit., pp. 172-173.

24 Sandra Walklate, Understanding Criminology-Current Theoretical Debates, Third Edition, England: Open University Press, 2007, p. 25.

25 Edward Eldefonso, et.al., op.cit., p. 312.

26 Edwin M. Schur, op.cit., p. 174.

27 Edward Eldefonso, et.al., op.cit., p. 316

$28 \quad$ Ibid, p. 319. 


\section{Abortion}

Abortion is termination of pregnancy before fetus birth. This article covers illegal abortion on purpose. People disapproval of abortion is related to expectation to preserve moral values that women should carry, not abort, babies. In some states, including Indonesia, illegal abortion is prohibited and punishable by law. It is stipulated in Article 346 to 349 of the Indonesian Penal Code. The article regulates that a woman who abort or order other people to abort her pregnancy faces punishment for maximum four years in prison. Other parties who perform abortion, whether or not with the pregnant woman concession, face maximum five years and six months. The article regulates that a woman who abort or order other people to abort her pregnancy faces punishment for maximum four years in prison. Other parties who perform abortion, whether or not with the pregnant woman concession, face maximum five years and six months. Doctors, midwives, or nurses who participate in the activity of abortion face an addition of one-third of punishment and their license to practice is revoked. The regulation reflects expectation of society towards abortion. The regulation, as can be observed, also covers illegal abortion clinics. As previously discussed, abortion is one of the crimes that triggers secondary crime.

The crime of abortion makes hospitals, professional doctors, midwives, and nurses cannot abort. Hence, illegal abortion clinics appears to provide the service of abortion with expensive price and low human resources and bad facility. A woman who wants to abort her pregnancy has to face the situation despite the fact that it is dangerous for her.

\section{The Aims of Punishment in Indonesian Criminal Law}

Packer argues that not all punishment is criminal punishment but all criminal punishment is certainly punishment. ${ }^{29}$ The given punishment can be in the forms other than criminal punishment but civil punishment or treatment. To explain his statement, Packer gives an example in the form of compensation as a punishment that is not considered criminal punishment. ${ }^{30}$

According to Packer, there are two main purposes of punishment. First, perpetrator should suffer pain for the crime act. Second, punishment is to prevent recurrence of the crime act. ${ }^{31}$ The first main purpose is called retributive theory; and the second is called utility theory. The two aims of punishment are included in three main aim of punishment theories. The third theory is a combination of retributive

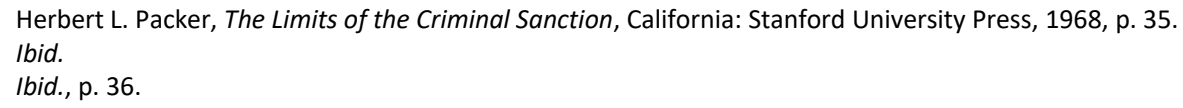


and utility theories. These three theories explain punishment given by state through law enforcement officers. ${ }^{32}$

1. Retributive Theory (vergeldingstheorien). In general, this theory covers crimes that contain elements that are punishable. Therefore, punishment becomes absolute condition as consequences of crime act. ${ }^{33}$ This theory answers the question concerning target of punishment and the severe of punishment. ${ }^{34}$

2. Utility Theory (doeltheorien/utilitarian). This theory covers the objection of retributive theory. In practice, sometimes, punishment is given with the intention to revenge. ${ }^{35}$ Moreover, retributive theory, unless Kranenburg Theory and religion-based theory, cannot explain clearly the reason of punishment by state. ${ }^{36}$ Punishment is not only aimed to revenge or to compensate people for crime act but also covers utility purpose. Therefore, this theory is called Utilitarian theory. ${ }^{37}$

3. Combine Theory (verenigingstheorien). This theory justifies punishment based on the principle of revenge and preserve order in society. Combine Theory merges retributive and utility theories to justify punishment. ${ }^{38}$ In general, the combine theory can be divided into three categories as follows. ${ }^{39}$

(1) First theory emphasizes on revenge principle. In this theory, revenge is still primary reason for punishment but the revenge should not exceeded the line of what it is needed and it is enough to maintain order in society.

(2) Second theory emphasizes on preserve order in society. This theory emphasizes on the maintenance of order in society to punish but the pain of the punishment should be heavier than the pain that caused by the crime act.

(3) Third theory emphasizes on the two previous principles. In this theory, the two principles should be implemented in balance.

In the Indonesian Penal Code Academic Paper Draft, it is mentioned that the aims of punishment are based on the balance of two main purposes of punishment to "protect the society" and deterrent. ${ }^{40}$ It is stated in Article 58 of the Indonesian Penal Code Draft.

\footnotetext{
E. Utrecht, Hukum Pidana I, Surabaya: Pustaka Tinta Mas, 1994, p. 158.

Ibid., p. 159.

Douglas Husak, Overcriminalization: The Limit of the Criminal Law, New York: Oxford University Press, 2008, p. 188.

E. Utrecht, Hukum Pidana I, op.cit., pp. 177-178.

Ibid., p. 178.

Muladi and Barda Nawawi, Teori-Teori dan Kebijakan Pidana-Edisi Revisi, Bandung: Alumni, 1998, p. 16.

E. Utrecht, Hukum Pidana I, op.cit., p. 186.

Ibid.

Indonesian Penal Code Academic Paper Draft, the National Law Development Agency, the Ministry of Law and Human Rights of the Republic of Indonesia [Draf Naskah Akademik Rancangan Undang-Undang tentang Kitab Undang-Undang Hukum Pidana (KUHP), Badan Pembinaan Hukum Nasional Kementerian Hukum dan Hak Asasi Manusia Republik Indonesia], pp. 35-36.
} 
Article 58

(1) The aims of punishment are:

a. to deter criminal act by enforcing legal norm for protection and guidance of society;

b. to edify prisoner by education and guidance to be a good and useful person in society.;

c. to settle conflict that is caused by criminal act, to restore the balance, and to secure peace in society; and

d. to encourage regret and to free guilty feeling of convicted person.

(2) Punishment should not be intended to suffer and to humiliate person.

Based on the purpose of society protection, which is an aim of punishment in Indonesian Penal Code Draft, the criminal law enforcement can be divided into the followings. ${ }^{41}$

1. Society protection from harmful anti-social act that endangers society. The objectives of punishment are to prevent and to eradicate crimes. In this purpose, punishment is to prevent incoming crime acts that may harm society. Thus, the act should be prevented and for the acts that have been committed should be overcome. Therefore, the crime can be resolved and not recurrent in the future.

2. Society protection from risk of a person. The punishment is to affect or to influence the behavior of perpetrator so that the perpetrator is willing obey the law and becomes a good and a useful citizen. The purpose is to recover and to change perpetrator's behavior so that similar crime will not occur in the future and the society is protected.

3. Society protection from sanction abuse or law enforcement officer's or citizen's reaction in general. The punishment is to prevent arbitrary reaction. The aim is to avoid sanction abuse or reaction abuse from law enforcement officer or people in general. Hence society can be protected from such abuse.

4. Society protection from disturbance on balance or interest conformity and value conformity due to crime act. Criminal law enforcement has to resolve conflicts that are caused by crime acts and criminal law enforcement has to restore the balance and to bring in peace within society. The protection includes protection of victims. Victim of power abuse also has to be protected with access to justice and fair treatment, restitution, compensation, and assistance.

To formulate criminal law norm and sentencing, at least three points have to be achieved by criminal law enforcement. They are: ${ }^{42}$

$41 \quad$ Ibid, pp. 3-4.

42 Tim Kerja, Perencanaan Pembangunan Hukum Nasional Bidang Hukum Pidana Dan Sistem Pemidanaan (Politik Hukum dan Pemidanaan), Jakarta: Badan Pembinaan Hukum Nasional, 2008, p. 10. 
(1) to formulate or to achieve social life ideals or society ideals;

(2) to maintain and to enforce honorable values within society; and

(3) to defend something that is ideal and followed by society with negative norm formulation technic.

According to Soekanto, law enforcement is a harmonious activity of values. It is spelled out to assess rules that are good and is manifested as interpretation of value to create, to maintain, and to preserve peacefulness within the life of society. ${ }^{43}$ Thus, to make a good law enforcement, Soekanto states five factors that affect the law enforcement such as Law, Law Officer, Facilities, Society, and Culture. ${ }^{44}$ According to the Indonesian Penal Code Draft, punishment aims to protect both society and individual and to educate convicted person. Therefore, the aim of punishment in the Indonesian Penal Code Draft is a utility theory because it emphasizes on prevention with social welfare as the final purpose. ${ }^{45}$

\section{Is Victimless Crime Punishable?}

Binder argues that punishment is not an act but it is an institution. ${ }^{46}$ It means that punishment should be a part of a system that consists of norms, a prestigious procedure to produces the norms, a prestigious procedure to enforce sentences, and some practical authority behaviors over persons or resources. ${ }^{47}$ Therefore, punishment is not just to harm perpetrator, nor just because perpetrator doing the crime act, but it should be an institutional authority conduct. Because punishment is a part of institutional authority system, the punishment legitimacy is bounded by norm legitimacy and the institution that enforced the norm asserts the punishment.

According to Smith and Pollack, victimless crime is one of mala prohibita. ${ }^{48}$ The debates over its punishment is arisen from the fact that this crime has no evil intention, as in mala in se. Hence, some scholar question the effectivity and the usability of law enforcement on this type of crime. In addition to the absence of evil intention, victimless crime is also considered having no negative effects. It is because the victim is also the perpetrator. The dangerous level of secondary crime caused by victimless crime is higher than the victimless crime itself. For example, in drug abuse, the secondary crime is more dangerous than the drug abuse itself. Drug abuse affects only the perpetrator, which is also the victim of the crime but an organized crime may lead to other crimes. For instance, drug dealer markets the product with

43 Soerjono Soekanto, "Masalah Penegakan Hukum dan Kesadaran Hukum", Jurnal Hukum dan Pembangunan Universitas Indonesia, Vol. 9, No. 5, 1979, p. 461.

44 Soerjono Soekanto, Faktor-Faktor yang Mempengaruhi Penegakan Hukum, Jakarta: Raja Grafindo Persada, 2007, pp. 17-18.

45 Indonesian Penal Code Academic Paper Draft, op.cit., p. 42.

46 Guyora Binder, "Punishment Theory: Moral or Political?", Buffalo Criminal Law Review, Vol. 5, 2002, p. 321.

47 Ibid.

48 Joseph F. Winterscheid, loc.cit. 
violence. They always try to recruit other drug abusers to buy their products so they get a high profit.

Secondary crime arises from a business opportunity to provide drugs for drug abusers or to provide services and facilities for other types of victimless crimes. Drugs become rare commodity because it is forbidden. The same happens to abortion clinics and casino. A woman who wants to abort her pregnancy has to abort in illegal clinics, which have no good facility and resources. Thus, it endangers her life. Abortion clinics exist because the woman who wants to abort her pregnancy will pay anything to abort her pregnancy.

Based on sub-culture theory, if we punish victimless crime, perpetrators may feel rejected by society. Thus, they will join fellow perpetrators to make a new subculture where victimless crime is accepted as a new value. A new sub-culture does not include perpetrators of victimless crimes but also perpetrators of secondary crimes. This new sub-culture always solicits new members. Instead of stopping, victimless crimes may grow faster in the new sub-culture because it always looks for a new member.

The appearance of new sub-culture makes heavier situation for law enforcement officers. It causes ineffective law enforcement. As Soekanto states that five factors affect law enforcement ${ }^{49}$. Law officers and facilities are two of the five factors. If a law officer cannot perform because of inefficient human resources and facilities, the law enforcement cannot be effective.

This condition can be seen from the number of prisoners who convicted victimless crimes. For example, drug abuse is one of victimless crimes. The prisoners of drug abuse on May 2019 form the second largest group in Indonesian correctional institutions amounting to 22.374 from the total $71.654 .{ }^{50}$ This condition triggers a question whether or not the law enforcement of drug abuse is effective.

The overcrowd of Indonesian correctional institutions. Moreover, punishment for drug abuser is not deter the perpetrators. The drug abuse even exists in correctional institutions. In fact, the circulation of drugs takes place at correctional institutions. Correctional institution becomes a safe place to make and to circulate illicit drugs. ${ }^{51}$

The discussion on the urgency of punishment for victimless crime generates a question on the aim of punishment. According to Packer, there are two main objectives of punishment theories: retributive and utility theories. In retributive theory, a traditional group assumes the main problem of punishment is that the

\footnotetext{
Soerjono Soekanto, Faktor-Faktor yang Mempengaruhi Penegakan Hukum, op.cit.

Sistem Database Permasyarakatan, "Data Terakhir Jumlah Khusus Penghuni Perkanwil," http://smslap.ditjenpas.go.id/public/krl/current/monthly/year/2019/month/5, downloaded on June 8, 2019.

51 Adi Briantika, "BNN Duga Lapas Masih Jadi Tempat Aman Mengendalikan Narkoba," https://tirto.id/bnn-dugalapas-masih-jadi-tempat-aman-mengendalikan-narkoba-djf2, downloaded on 12 June 2019.
} 
violation of law is also immoral or breaking natural order so the perpetrator "deserves" a punishment. ${ }^{52}$

On the other hand, the utility theory views the objective of punishment is to punish an offence. In general, this theory views punishment as a prevention and it has to give benefit for society. However, in fact their argument also considering "desert". ${ }^{33}$ It is because punishment should be made equal to the impact of the crime either to perpetrator's self or to society.

Based on the objectives of punishment from the main theories, punishment of victimless crime can be accepted only in retributive theory. The utility theory cannot accept the punishment for victimless crime because a punishment should be beneficial for the perpetrator and for society. Sentences should equal to the impact to both the perpetrator and society.

It is important to reconsider the necessity of punishment for victimless crime. The data of the number of drug abusers in correctional institutions, on May 2019, shows that they comprise $31,2 \% .{ }^{54}$ Likewise, the dangerous of secondary crime that follows victimless crime should be considered prior to declaring the necessity of punishment for victimless crime since secondary crime can be more dangerous than the victimless crime itself. The two reasons and the objective of punishment for victimless crime must considered collectively.

\section{E. Conclusion}

In the discussion of punishment for victimless crime, there are two opposite views arguing for either punishable or not. According to Binder, "punishment should be seen as an institution rather than a behavior and should be evaluated politically rather than ethically". ${ }^{55}$ Hereafter, it the punishment for morally wrong conduct is not important.

Victimless crime, according to Schur is a deviant behavior that is wrong morally and it is standardized as a crime. Smith and Pollack states that victimless crime is included into mala prohibita conduct. ${ }^{56}$ Based on Binder's argument, victimless crime should not be punished since it is only a morally wrong conduct.

Then, the appearance of secondary crime is more dangerous than victimless crime. As mentioned earlier, victimless crime is always be followed by secondary crime. Rare goods, services, and facilities with high demand shall be observed as

\footnotetext{
52 David A. Starkweather, "The Retributive Theory of "Just Deserts" and Victim Participation in Plea Bargaining", Indiana Law Journal, Vol. 67, Issue 3, 1992, p. 855

53 Llyod L. Winreb, "Desert, Punishment, and Criminal Responsibility", Law and Contemporary Problems, Bo. 49 No. 3, 1986, p. 47.

54 Sistem Database Permasyarakatan, "Data Terakhir Jumlah Khusus Penghuni Perkanwil," http://smslap.ditjenpas.go.id/public/krl/current/monthly/year/2019/month/5, downloaded on 8 June 2019.

55 Guyora Binder, op.cit. p. 366.

56 Joseph F. Winterscheid, loc.cit.
} 
potential profit for other parties. Subsequently, it may lead to the emergence of secondary crime to fulfil the demands.

In addition to secondary crime, prohibited victimless crime may trigger the emergence of a new sub-culture that gathers both victimless crime and secondary crime perpetrators. This circumstance makes law enforcement ineffective since the group of perpetrators will always do the same crime and may even try to persuade others to become new members.

In Indonesian correctional institutions, the number of drug offence prisoners is higher than a half of all special crime population. Drug dealer comprise $63,3 \%$ of drug offence prisoners and $31,2 \%$ is drug abuser. Thus, drug offence contributes number of prisoners more than other special crime in Indonesian correctional institutions.

This condition makes the objective of punishment and law enforcement of victimless crime questionable because the law enforcement is ineffective. The work of law enforcement is heavy and the crime is always rising. Hereafter, punishment for victimless crime should be reconsidered as Schur's statement, "victimless crime is a deviant behavior" and Binder's argumentation that immoral conduct should not be punished.

\section{References}

\section{Books}

E. Utrecht, Pengantar Dalam Hukum Indonesia, Cetakan Kesembilan, PT. Penerbitan Universitas, Jakarta, 1966.

-, Hukum Pidana I, Pustaka Tinta Mas, Surabaya, 1994.

Eldefonso, Edward, et.al., Principles of Law Enforcement, Second Edition, John Wiley \& Son, Canada, 1968.

Husak, Douglas, Overcriminalization: The Limit of the Criminal Law, Oxford University Press, New York, 2008.

M. Schur, Edwin, Crimes Without Victims-Deviant Behavior and Public Policy: Abortion, Homosexuality, Drug Addiction, Prentice-Hall, Englewood Cliff, New Jersey, 1965.

Muladi and Barda Nawawi, Teori-Teori dan Kebijakan Pidana-Edisi Revisi, Alumni, Bandung, 1998.

Newburn, Tim, Criminology, Wilan Publishing, Oregon, 2007.

Packer, Herbert L., The Limits of the Criminal Sanction, Stanford University Press, California, 1968.

Soerjono Soekanto, Faktor-Faktor yang Mempengaruhi Penegakan Hukum, Raja Grafindo Persada, Jakarta, 2007.

Tak, P.J.P., The Dutch Criminal Justice System, Wolf Legal Publishers, CB Nijmegen, 2008. 
Tim Kerja, Perencanaan Pembangunan Hukum Nasional Bidang Hukum Pidana Dan Sistem Pemidanaan (Politik Hukum dan Pemidanaan), Badan Pembinaan Hukum Nasional, Jakarta, 2008.

Walklate, Sandra, Understanding Criminology-Current Theoretical Debates, Third Edition, Open University Press, England, 2007.

\section{Other Documents}

Adi Briantika, "BNN Duga Lapas Masih Jadi Tempat Aman Mengendalikan Narkoba", https://tirto.id/bnn-duga-lapas-masih-jadi-tempat-aman-mengendalikannarkoba-djf2, downloaded on 12 June 2019.

Binder, Guyora, "Punishment Theory: Moral or Political?", Buffalo Criminal Law Review, Vol. 5, 2002.

De Waard, Jaap, "The Crime Drop in The Netherlands and other industrialized countries: Trends and possible explanations", Working Paper, May 2015.

Liberal Democratic Party Austria, "Policy: Victimless Crime", https://ldp.org.au/wpcontent/uploads/policies/Policy-VictimlessCrimes.pdf downloaded on 14 December 2016.

Mardjono Reksodiputro, "Perkembangan Hukum Pidana Materiil dan Formil Dalam Undang-Undang DI Luar KUHP (Catatan Sementara Tentang Pengaruhnya Terhadap Pembangunan Sistem Hukum Pidana Nasional)", this paper is presented at Lokakarya Perencanaan Pembangunan Hukum Nasional, Badan Pembinaan Hukum Nasional Kementerian Hukum dan Hak Asasi Manusia, Semarang, 4 November 2010.

Moore, Gerard, et.al., "A Review of Harm Reduction Approaches in Ireland and Evidence from the International Literature", the Stationery Office, Dublin, May 2004.

Sistem Database Permasyarakatan, "Data Terakhir Jumlah Khusus Penghuni Perkanwil,"

http://smslap.ditjenpas.go.id/public/krl/current/monthly/year/2019/month/5, downloaded on 8 June 2019.

Soerjono Soekanto, "Masalah Penegakan Hukum dan Kesadaran Hukum", Jurnal Hukum dan Pembangunan Universitas Indonesia, Vol. 9 No. 5, 1979.

Starkweather, David A., "The Retributive Theory of "Just Deserts" and Victim Participation in Plea Bargaining", Indiana Law Journal, Vol. 67, Issue 3, 1992.

Status Paper on Prisons, "Drugs and Harm Reduction", WHO Regional Office, May 2005,

http://www.euro.who.int/ data/assets/pdf file/0006/78549/E85877.pdf, downloaded on May 28, 2018.

Van Ooyen-Houben, Marianne dan Edward Kleemans, "Drug Policy : The "Dutch Model", Crime and Justice, July 2015. 
Winreb, Llyod L., Desert, "Desert, Punishment, and Criminal Responsibility", Law and Contemporary Problems, Bo. 49, No.3, 1986.

Winterscheid, Joseph F., "Victimless Crimes: The Threshold Question and Beyond", Notre Dame Law Review, Vol. 52, Issue 5.

\section{Legal Documents}

Indonesian Penal Code [Kitab Undang-Undang Hukum Pidana].

Law Number 5 of 1997 on Psychotropic [Undang-Undang Nomor 15 Tahun 1997 tentang Psikotropika].

Law Number 35 of 2009 on Narcotics [Undang-Undang Nomor 35 Tahun 2009 tentang Narkotika].

Indonesian Penal Code Draft [Rancangan Undang-Undang Kitab Undang-Undang Hukum Pidana].

Indonesian Penal Code Academic Paper Draft, National Law Development Agency Ministry of Law and Human Rights Republic of Indonesia [Draf Naskah Akademik Rancangan Undang-Undang tentang Kitab Undang-Undang Hukum Pidana (KUHP), Badan Pembinaan Hukum Nasional Kementerian Hukum dan Hak Asasi Manusia Republik Indonesia]. 